\title{
Effect of Anger and Anger Management Skills during the Covid-19 Pandemic: A Survey
}

\author{
Ankit Singh ${ }^{1}$, Namita Sharma ${ }^{2}$, Somesh Kumar Sahay ${ }^{3}$ \& Anju Meshram ${ }^{*}$ \\ ${ }^{1-4}$ Department of Biotechnology, Kalinga University, Naya Raipur, Chhattisgarh, India. \\ ${ }^{4 *}$ Corresponding Author: Dr. Anju Meshram, Assistant Professor, Department of Biotechnology, Kalinga \\ University, Kotni, Naya Raipur-490121, Chhattisgarh. Email: anjumeshram001@ gmail.com
}

The purpose of present study was to investigate anger and related issues among individuals during the Covid-19 pandemic situation. The online survey was conducted among varied age groups to analyse the effect of pandemic conditions on the mental health of individuals. A total of 233 people participated in this online survey from different educational backgrounds and professions to help in the analysis of cause of anger, its effect on larger areas including family, work, health and society as a whole. This study also focused on various approaches of anger management and importance of family and healthy social circle on the mental health of an individual. The results of present study revealed that people who are not engaged actively in social behaviour or under peer guidance suffer more due to anger and related issues whereas individuals who practiced healthy habits like yoga, meditation or exercise showed better anger management skills.

Keywords: Anger expression, Anger management, Emotional sensitivity, Health effects, Social skill.

\section{Introduction}

Anger management is the main domain in socio-psychology and behavioural science where professionals try to help people by giving information about the skills, as well as inform them about the potential health or bio psychosocial risk on their selves and their environment. Anger management is done by understanding the nature of their anger, focusing on conceptualizing anger with other people, situations, and angry events, and thoughts, images, and physical cues that indicate increased anger [1].

Aggression is a behavior that is often found in children and adults [2-3]. Emotional conditions are relatively unstable which can be a trigger aggression, in the study show that if individuals can manage their emotions, it can reduce the risk of maladaptive behavior, including aggression behavior [4].

Problems with anger and aggression are the most common things found in adolescents. The inability to control the emotions of anger can be a trigger for the emergence of aggression. Anger management is the ability to regulate thoughts, feelings, lust, and anger in the right way and positively and socially acceptable. Studies have shown that anger management only has a mild to medium effect on reducing negative emotions and negative behavior including aggression [5]. Another study explained that anger management training can reduce total aggression which in school teenagers [6].

Anger management is the skill to recognize signs that you are angry, and take action to deal with situations in a positive way. Anger is a normal human emotion and healthy when properly expressed.

Problems related to anger are one of the most common reasons why children and adolescents are referred for psychological services [7]. The terms anger, hostility and aggression are often used interchangeably. However, some researchers consider that hostility, anger and aggression can represent the cognitive, affective and behavioral components of the same multidimensional construction [8]. 


\section{Material and Method}

Present study was based on online survey using the Google form. The study was carried out during the Covid-19 pandemic between April 2021 to June 2021 and a total of 233 response was recorded. The questionnaire was designed to study the cause of anger and anger management skill among different age groups and gender. A total of 15 questions were asked for this purpose including their gender, age group, profession and views upon anger and its management (Table 1).

Table 1. Questions used in the online survey for study of anger management

\begin{tabular}{|c|c|c|c|c|}
\hline Questions & Opt A & Opt B & Opt C & Opt D \\
\hline Did you get anger? & Always & Yes & Sometimes & No \\
\hline Causes of anger? Long work time / Insult & Always & Very often & Sometimes & Rarely/No \\
\hline $\begin{array}{l}\text { It makes me angry if someone lies to me } \\
\text { or cheats on me? }\end{array}$ & Agree & $\begin{array}{l}\text { Strongly } \\
\text { agree }\end{array}$ & Never & Somewhat agree \\
\hline $\begin{array}{l}\text { If things don't go according to my way; I } \\
\text { get into an argument even against my } \\
\text { will }\end{array}$ & Agree & $\begin{array}{l}\text { Strongly } \\
\text { agree }\end{array}$ & Never & Somewhat agree \\
\hline $\begin{array}{l}\text { I find myself frequently annoyed with } \\
\text { certain friends or family }\end{array}$ & Yes & Always & No & Sometimes \\
\hline $\begin{array}{l}\text { I can't tolerate incompetence. It makes } \\
\text { me angry }\end{array}$ & Agree & $\begin{array}{l}\text { Strongly } \\
\text { agree }\end{array}$ & Never & Somewhat agree \\
\hline $\begin{array}{l}\text { When a situation makes me angry, I'm } \\
\text { still able to focus and work to resolve the } \\
\text { situation }\end{array}$ & Agree & $\begin{array}{l}\text { Strongly } \\
\text { agree }\end{array}$ & Never & Somewhat agree \\
\hline $\begin{array}{l}\text { Do you feel any health effect after } \\
\text { anger? }\end{array}$ & Headache & $\begin{array}{l}\text { Rapid } \\
\text { breathing }\end{array}$ & $\begin{array}{l}\text { Smoking and } \\
\text { drinking alcohol }\end{array}$ & Lack of sleep \\
\hline $\begin{array}{l}\text { I embarrass family, friends, or co-worker } \\
\text { with my anger outbursts }\end{array}$ & Agree & $\begin{array}{l}\text { Strongly } \\
\text { agree }\end{array}$ & Disagree & Somewhat agree \\
\hline $\begin{array}{l}\text { I remember people and situations that } \\
\text { make me angry for a long time }\end{array}$ & Agree & $\begin{array}{l}\text { Strongly } \\
\text { agree }\end{array}$ & Disagree & Somewhat agree \\
\hline $\begin{array}{l}\text { What do you do to cope up with your } \\
\text { anger? }\end{array}$ & $\begin{array}{l}\text { Yoga or } \\
\text { mediation }\end{array}$ & $\begin{array}{l}\text { Sports or } \\
\text { gym }\end{array}$ & $\begin{array}{l}\text { Laughing } \\
\text { therapy }\end{array}$ & Listen to music \\
\hline $\begin{array}{l}\text { To whom do you look forward to } \\
\text { manage your anger? }\end{array}$ & Friend & Spouse & $\begin{array}{l}\text { Family and } \\
\text { relatives }\end{array}$ & Pet names \\
\hline
\end{tabular}




\section{Result and Discussion}

The study was carried out during the Covid-19 pandemic between April 2021 to June 2021and a total of 233 response was recorded of which 106 were male and 127 were female. $82 \%$ of the respondents belonged to the age group of $15-25$ years where $54.5 \%$ are undergraduate students. Of the total respondents only $3 \%$ people said they do not get anger while $62.7 \%$ said that they get anger sometimes, $21.9 \%$ gets angry often and $12.4 \%$ always gets anger. The results based on survey showed that for majority of persons the cause of anger was long working duration and some kind of insult (Fig.1).

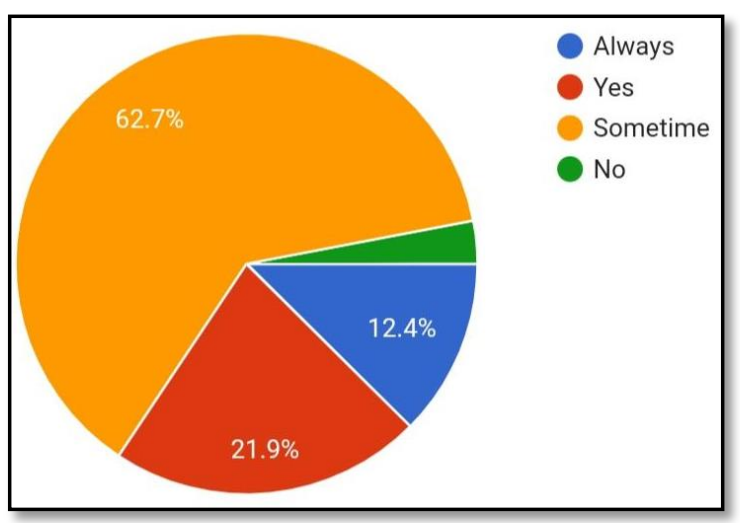

(a)

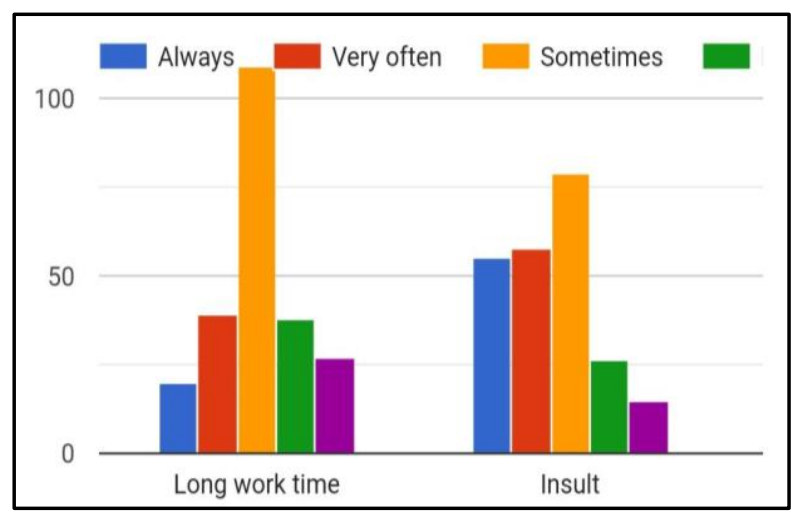

(b)

Fig.1. Response on (a) Did you get anger? (b) Cause of anger?

A maximum of $38.2 \%$ people agreed that the cause of anger is when someone lies to them or cheats upon them while $9.9 \%$ people said that these factors have never made them angry. Mixed response was received for argument against the will where $30 \%$ respondents said that they never get involved in the argument against their will while $30 \%$ people were somewhat agree to this situation (Fig.2).

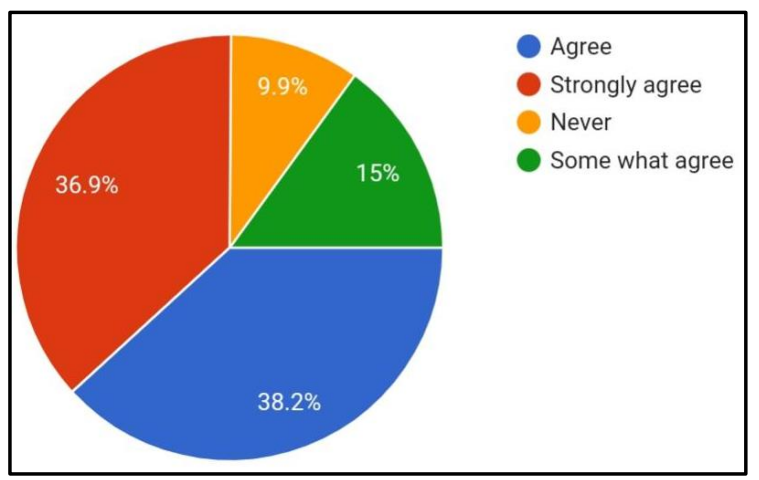

(a)

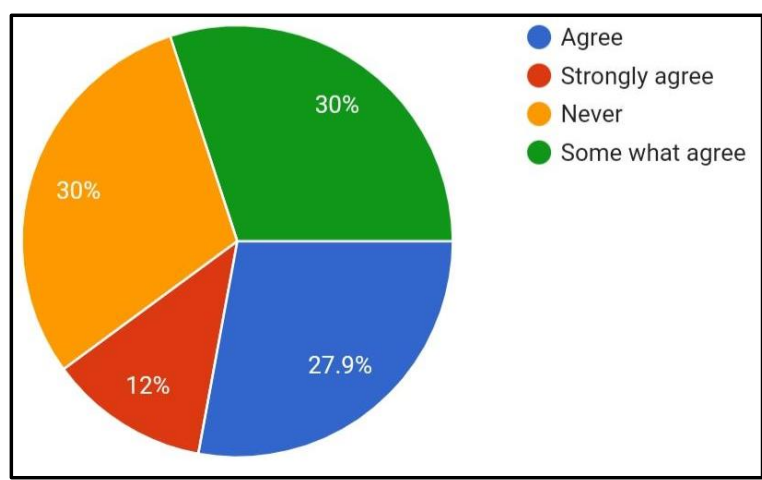

(b)

Fig.2. Response on (a) It makes me angry if someone lies to me or cheats on me (b) If things don't go according to my way; I get into an argument even against my will

The affect of Covid-19 and pandemic lockdown could be seen on majority of the respondents where 39\% people said that they frequently get annoyed with certain friends or family members and 22.7 gave negative response. Also $9 \%$ respondents strongly agreed that they cannot tolerate incompetence and become angry while $30.9 \%$ have disagreed to the incompetence factor as the cause of anger (Fig.3). 


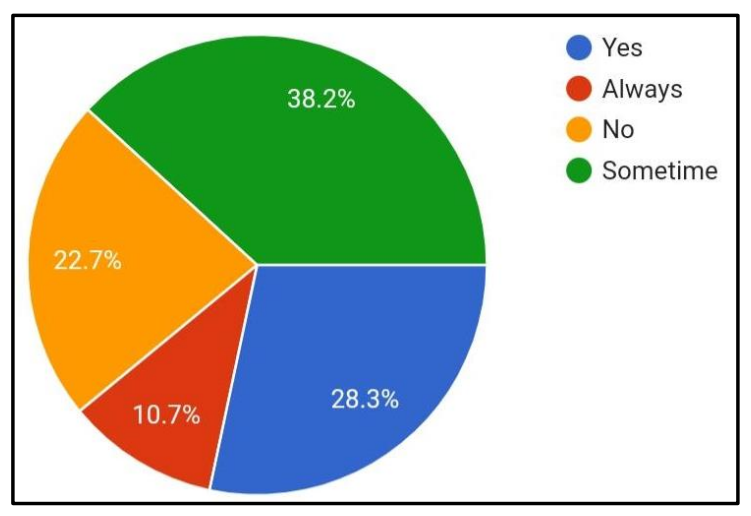

(a)

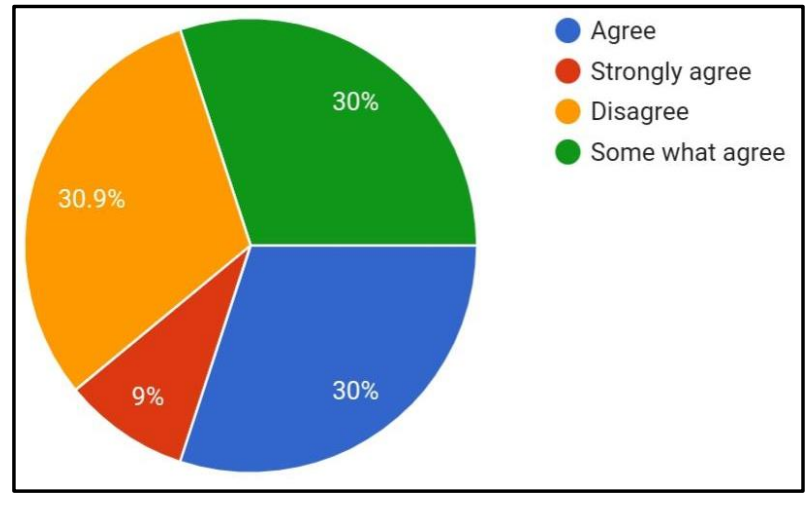

(b)

Fig.3. Response on (a) I find myself frequently annoyed with certain friends or family (b) I can't tolerate incompetence, it makes me angry

Of the 233 respondents, 149 people agreed that under the anger condition, they could focus and work to resolve the situation whereas 39 people disagreed to this and said they cannot work effectively under this situation. Also the effect of anger was analysed on the health. 54.9\% respondents agreed that they feel headache after anger, $27.5 \%$ faced sleep disorders, while 3.4\% people said that they drink or smoke to cope up with anger (Fig.4).

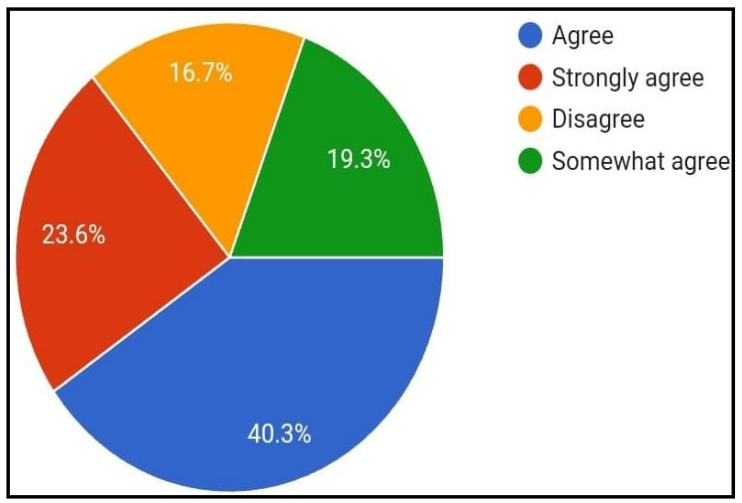

(a)

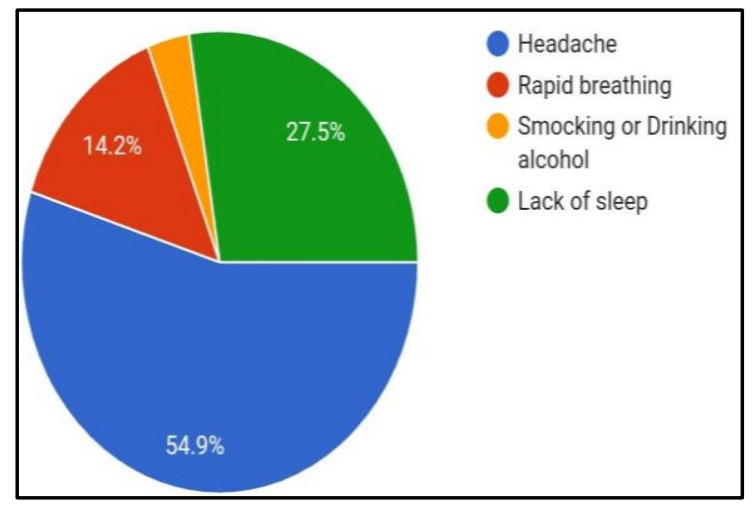

(b)

Fig.4. Response on (a) When a situation makes me angry, I'm still able to focus and work to resolve the situation (b) Do you feel any health effect after anger?

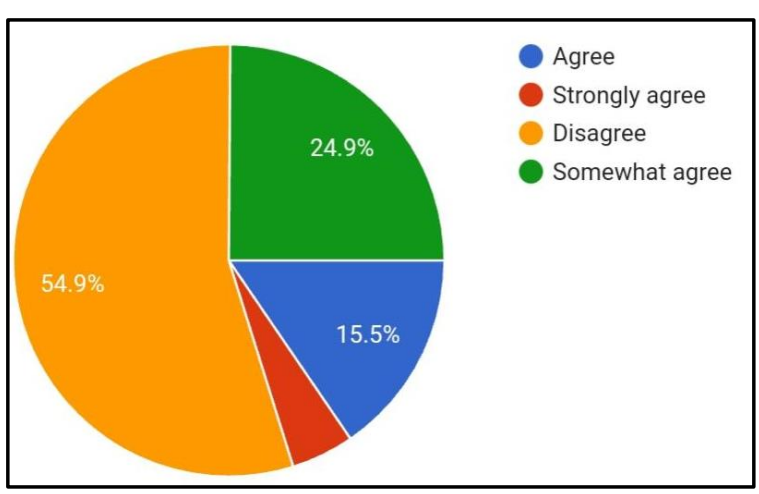

(a)

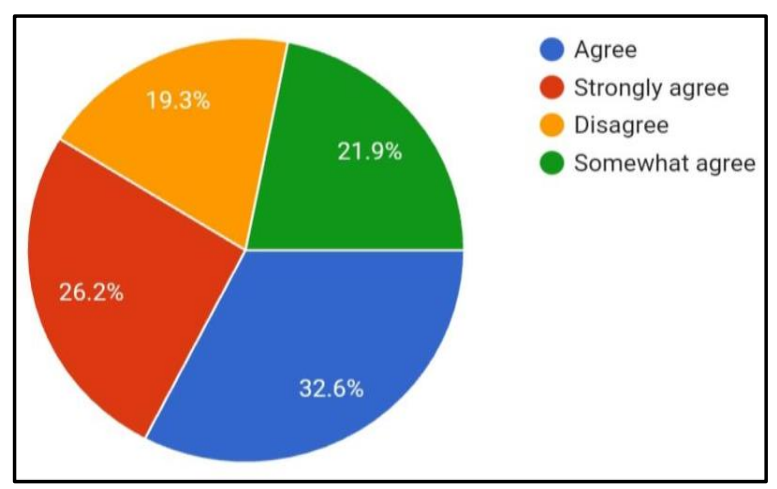

(b)

Fig.5. Response on (a) I embarrass family, friends, or co-worker with my anger outbursts (b) I remember people and situations that make me angry for a long time 


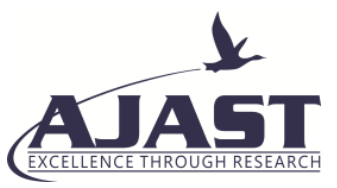

Asian Journal of Applied Science and Technology (AJAST)

Volume 5, Issue 3, Pages 177-183, July-September 2021

Current study shows that $15.5 \%$ of respondents feel that due to anger outburst, they embarrass family, friends or co-workers while $54.9 \%$ people disagreed to this situation. Results of the present study indicates that out of 233 respondents, 137 people remember the people and situation that had made them angry for a long time while 50 people forget these things easily (Fig.5).

As the anger management strategy, $67.4 \%$ respondents chose listening to music, $10.3 \%$ prefer yoga or meditation, $11.2 \%$ desire for physical activity like sports or gym and the remaining $11.2 \%$ favour laughing therapy to cope up with the anger. In the similar fashion for anger management, $50.2 \%$ of the respondents look forward to their friends, $26.8 \%$ look forward to their family and relatives during the anger management, $15.6 \%$ preferred pet animals while only $7.4 \%$ look forward to their spouse for anger management (Fig.6).

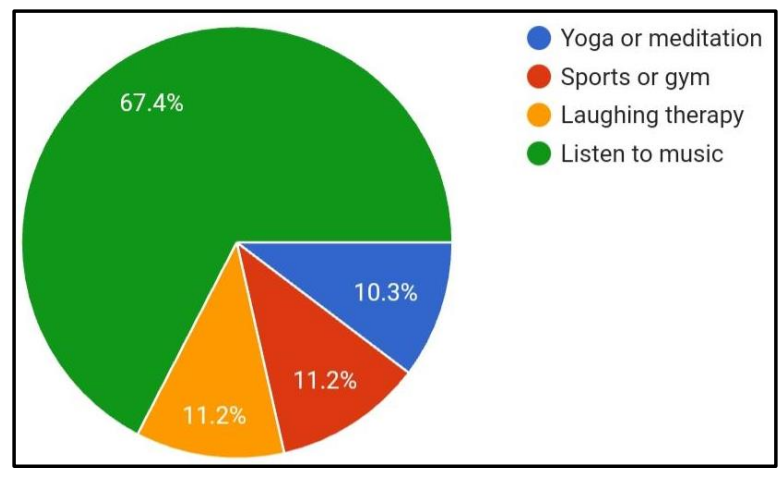

(a)

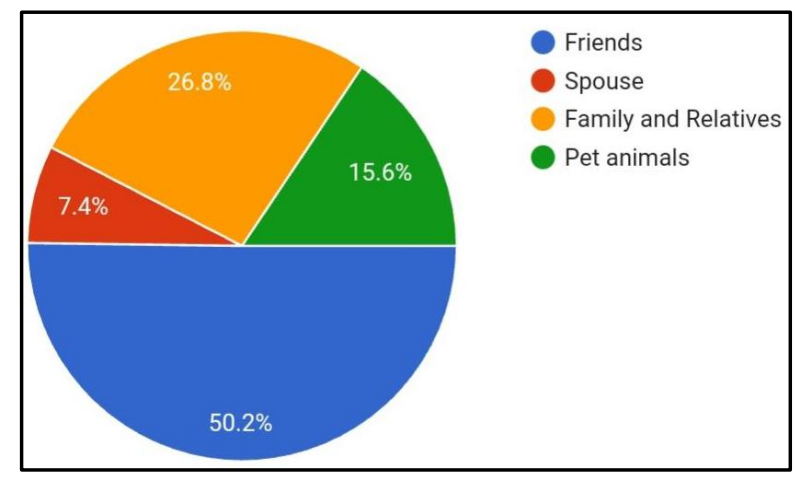

(b)

Fig.6. Response on (a) What do you do to cope up with your anger? (b) To whom do you look forward to manage your anger?

This research result indicated that there was direct relation between anger management to aggression behaviour. During the pandemic conditions of Covid-19, social behaviour of human beings got affected. Restrictions to home and online work and education had an impact on the mental health and behaviour of individuals. Majority of the respondents involved in the current study realized that anger had some negative effects on their friends or family and most of them also experienced health hazards due to anger.

At the same time, the outcome of this study suggests that people have awareness about the ill-effects of anger and knows how to control anger related emotions. This study shows that people are involved in several healthy habits like yoga, meditation, sports, gym, etc. and rely on them for anger management. This is accordance with research that anger management can support children to control the emotions so that maladaptive behavior can be decreased [5]. Another research mentioned that it will be more effective when extra treatment is given to drop the aggression behavior. Previous studies also mentioned that cognitive behaviour therapy (CBT) is the most effective treatment to drop the children's aggression behavior so that children's learn about good coping strategy and with role play, so that unwanted negative behavior can be prevented $[9,10]$.

In the present survey, several respondents have mentioned that the company of friends and family help them in anger management. This is in accordance with the previous study which proves that the moderating effect of social skills is quite good in anger management and aggression relationships. Some other studies also prove this, related to 


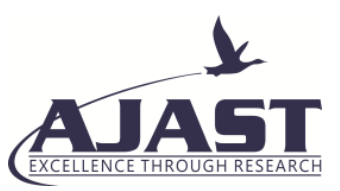

Asian Journal of Applied Science and Technology (AJAST)

Volume 5, Issue 3, Pages 177-183, July-September 2021

social skills and aggression. Different research findings show that social skills training can reduce social anxiety, generalized delinquency depression, anger, social disturbances, inability to adapt, negative behaviour towards peers, and many other emotional and behavioural problems [11]. Social skills training positively influences student behaviour including reducing anger and negative consequences, controlling excitement and feeling relieved [12]. Thus social skills can be an effective moderation in reducing aggression with anger management in individuals.

\section{Conclusion}

The survey report of present study indicates direct relation between anger and current pandemic situation. Certain changes in the lifestyle, social behaviour, education and working conditions have created an impact on the mental health of people as well. Most of the respondents who belonged to the young age and involved in the current study realized that anger had some negative effects on their friends or family and most of them experienced certain health hazards also. Overall outcome of the current study suggests that people knows how to control anger related emotions and work effectively on the anger management skills. Based on the results of the analysis carried out in this study, it can be concluded that there is a moderating effect of social skills on the relationship between anger and its control.

\section{Acknowledgement}

The authors are thankful to all the higher authorities of Kalinga University, Naya Raipur for providing necessary facilities and support to conduct this study.

\section{Declarations}

\section{Source of Funding}

This research did not receive any grant from funding agencies in the public, commercial, or not-for-profit sectors.

\section{Competing Interests Statement}

The authors declare no competing financial, professional and personal interests.

\section{Consent for publication}

Authors declare that they consented for the publication of this research work.

\section{References}

[1] P.M. Reilly, W. Clark, M.S. Shopshire, E.W. Lewis, D.J. Sorensen, Anger management and temper control: Critical components of posttraumatic stress disorder and substance abuse treatment, National Institue on Drug Abuse (1990).

[2] R. Loeber, D. Hay, Key issues in the development of aggression and violence from childhood to early adulthood, Annual Review of Psychology, 48:1 (1997) 371-410.

[3] P.H. Tolan, D. Gorman-Smith, R. Loeber, Developmental timing of onsets of disruptive behaviors and later delinquency of inner-city youth. Journal of Child and Family Studies, 9:2 (2000) 203-220. 
[4] T. Roberton, M. Daffern, R.S. Bucks, Emotion regulation and aggression. Aggression and Violent Behavior, 17 (2012) $72-82$.

[5] A.M. Candelaria, A.L. Fedewa, S. Ahn, The effects of anger management on children's social and emotional outcomes: A meta-analysis, School Psychology International, 33:6 (2012) 596-614.

[6] S. Valizadeh, R.B.O Davaji, M. Nikamal, The effectiveness of anger management skills training on reduction of aggression in adolescents, Procedia - Social and Behavioral Sciences, 5:2 (2010) 1195-1199.

[7] H. Abikoff, R.G. Klein, Attention-deficit hyperactivity and conduct disorder: Comorbidity and implications for treatment, Journal of Consulting and Clinical Psychology, 60:6 (1992) 881-892.

[8] A.H. Buss, M. Perry. Personality process and individual the aggression questionare. Journal of Personality, 63:3 (1992) $452-459$.

[9] K.A. Gansle, The effectiveness of school-based anger interventions and programs: A meta-analysis, Journal of School Psychology, 43:4 (2005) 321-341.

[10] D.G. Sukhodolsky, H. Kassinove, B.S. Gorman, Cognitive-behavioral therapy for anger in children and adolescents: A meta-analysis, Aggression and Violent Behavior, 9:3 (2004) 247-269.

[11] M.J. Prinstein, A.M. La Greca, Childhood peer rejection and aggression as predictors of adolescent girls' externalizing and health risk behaviors: A 6-year longitudinal study, Journal of Consulting and Clinical Psychology, 72 (2004) 103-112.

[12] J.L.Deffenbacher, D.A. Story, R.S. Stark, J.A. Hogg, A.D. Brandon, Cognitive-relaxation and social skills interventions in the treatment of general anger, Journal of Counselling Psychology, 34:2 (1987) 171-176. 